\title{
Front Matter: Volume 7202
}

, "Front Matter: Volume 7202," Proc. SPIE 7202, Laser-based Micro- and Nanopackaging and Assembly III, 720201 (12 March 2009); doi:

10.1117/12.824391

SPIE Event: SPIE LASE: Lasers and Applications in Science and Engineering, SPIE. 2009, San Jose, California, United States 


\title{
PROCEEDINGS OF SPIE
}

\section{Laser-based Micro- and Nanopackaging and Assembly III}

\author{
Wilhelm Pfleging \\ Yongfeng Lu \\ Kunihiko Washio \\ Willem Hoving \\ Jun Amako \\ Editors
}

28-29 January 2009

San Jose, California, United States

Sponsored and Published by

SPIE

Volume 7202 
The papers included in this volume were part of the technical conference cited on the cover and title page. Papers were selected and subject to review by the editors and conference program committee. Some conference presentations may not be available for publication. The papers published in these proceedings reflect the work and thoughts of the authors and are published herein as submitted. The publisher is not responsible for the validity of the information or for any outcomes resulting from reliance thereon.

Please use the following format to cite material from this book:

Author(s), "Title of Paper," in Laser-based Micro- and Nanopackaging and Assembly III, edited by Wilhelm Pfleging, Yongfeng Lu, Kunihiko Washio, Willem Hoving, Jun Amako, Proceedings of SPIE Vol. 7202 (SPIE, Bellingham, WA, 2009) Article CID Number.

ISSN 0277-786X

ISBN 9780819474483

Published by

SPIE

P.O. Box 10, Bellingham, Washington 98227-0010 USA

Telephone +1 3606763290 (Pacific Time) · Fax +1 3606471445

SPIE.org

Copyright (C) 2009, Society of Photo-Optical Instrumentation Engineers

Copying of material in this book for internal or personal use, or for the internal or personal use of specific clients, beyond the fair use provisions granted by the U.S. Copyright Law is authorized by SPIE subject to payment of copying fees. The Transactional Reporting Service base fee for this volume is $\$ 18.00$ per article (or portion thereof), which should be paid directly to the Copyright Clearance Center (CCC), 222 Rosewood Drive, Danvers, MA 01923. Payment may also be made electronically through CCC Online at copyright.com. Other copying for republication, resale, advertising or promotion, or any form of systematic or multiple reproduction of any material in this book is prohibited except with permission in writing from the publisher. The CCC fee code is 0277-786X/09/\$18.00.

Printed in the United States of America.

Publication of record for individual papers is online in the SPIE Digital Library.

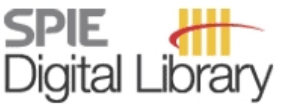

SPIEDigitalLibrary.org

Paper Numbering: Proceedings of SPIE follow an e-First publication model, with papers published first online and then in print and on CD-ROM. Papers are published as they are submitted and meet publication criteria. A unique, consistent, permanent citation identifier (CID) number is assigned to each article at the time of the first publication. Utilization of CIDs allows articles to be fully citable as soon they are published online, and connects the same identifier to all online, print, and electronic versions of the publication. SPIE uses a six-digit CID article numbering system in which:

- The first four digits correspond to the SPIE volume number.

- The last two digits indicate publication order within the volume using a Base 36 numbering system employing both numerals and letters. These two-number sets start with 00, 01, 02, 03, 04 , 05, 06, 07, 08, 09, OA, OB ... 0Z, followed by 10-1Z, 20-2Z, etc.

The CID number appears on each page of the manuscript. The complete citation is used on the first page, and an abbreviated version on subsequent pages. Numbers in the index correspond to the last two digits of the six-digit CID number. 


\title{
Contents
}

\author{
vii Conference Committee \\ ix Introduction
}

\section{OPTICAL COMPONENTS AND DEVICES}

720202 Integration of micro-optics and microfluidics in a glass chip by fs-laser for optofluidic applications (Invited Paper) [7202-01]

R. Osellame, R. Martinez, P. Laporta, R. Ramponi, G. Cerullo, Instituto di Fotonica e Nanotecnologie, CNR, Politecnico di Milano (Italy)

720203 Parametric investigation of solder bumping for assembly of optical components [7202-02] T. Burkhardt, Fraunhofer-Institut für Angewandte Optik und Feinmechanik (Germany) and Friedrich-Schiller-Univ. Jena (Germany); M. Hornaff, E. Beckert, R. Eberhardt, Fraunhofer-Institut für Angewandte Optik und Feinmechanik (Germany); A. Tünnermann, Fraunhofer-Institut für Angewandte Optik und Feinmechanik (Germany) and Friedrich-Schiller-Univ. Jena (Germany)

720204 New packaging concepts for highly stable laser diode modules (Invited Paper) [7202-03] E. Werner, S. Kretzschmar, G. Bonati, JENOPTIK Laserdiode GmbH (Germany); R. Eberhardt, Fraunhofer-Institut für Angewandte Optik und Feinmechanik (Germany)

720205 Laser splicing of end caps: process requirements in high power laser applications [7202-04] S. Boehme, E. Beckert, R. Eberhardt, A. Tuennermann, Fraunhofer-Institut für Angewandte Optik und Feinmechanik (Germany)

\section{DIRECT-WRITE PROCESSING AND SURFACE MODIFICATION}

720206 Submicron writing by laser irradiation on metal nano-particle dispersed films toward flexible electronics (Invited Paper) [7202-05]

A. Watanabe, M. Aminuzzaman, T. Miyashita, Tohoku Univ. (Japan)

720207 Laser-assisted structuring and modification of $\mathrm{LiCoO}_{2}$ thin films [7202-06]

R. Kohler, J. Proell, S. Ulrich, V. Trouillet, S. Indris, Forschungszentrum Karlsruhe (Germany); M. Przybylski, ATL Lasertechnik GmbH (Germany); W. Pfleging, Forschungszentrum Karlsruhe (Germany)

720209 Controlled-growth of single-walled carbon nanotubes using optical near-field effects [7202-08]

W. Xiong, Y. S. Zhou, M. Mahjouri-Samani, W. Q. Yang, K. J. Yi, X. N. He, Y. F. Lu, Univ. of Nebraska, Lincoln (United States)

7202 OA Local modification of ceramic surfaces by a laser induced cladding process [7202-09] S. Schreck, M. Rohde, Forschungszentrum Karlsruhe (Germany) 
7202 OB Multiscale modeling of phase changes during femtosecond laser metal interaction (Invited Paper) [7202-10]

X. Li, L. Jiang, Beijing Institute of Technology (China); H.-L. Tsai, Missouri Univ. of Science and Technology (United States)

7202 0C Comprehensive laser beam characterization for applications in material processing (Invited Paper) [7202-11]

K. Mann, A. Bayer, M. Lübbecke, B. Schäfer, Laser-Lab. Göttingen e.V. (Germany)

7202 OD Laser-induced breakdown spectroscopy with high detection sensitivity [7202-12]

X. K. Shen, H. Ling, Y. F. Lu, Univ. of Nebraska, Lincoln (United States)

7202 OE Mapping of individual single-walled carbon nanotubes using nano-Raman spectroscopy [7202-13]

X. N. He, K. J. Yi, Y. F. Lu, Univ. of Nebraska, Lincoln (United States)

\section{PROCESSES FOR MEMS}

7202 OF Low-stress dicing assisted by pulsed laser for multilayer MEMS (Invited Paper) [7202-14] M. Fujita, Institute for Laser Technology (Japan); Y. Izawa, Y. Tsurumi, Osaka Univ. (Japan); S. Tanaka, H. Fukushi, Tohoku Univ. (Japan); K. Sueda, Y. Nakata, N. Miyanaga, Osaka Univ. (Japan); M. Esashi, Tohoku Univ. (Japan)

$72020 \mathrm{G} \quad$ High quality laser cleaving process for mono- and polycrystalline silicon [7202-15] O. Haupt, V. Schuetz, A. Schoonderbeek, L. Richter, R. Kling, Laser Zentrum Hannover e.V. (Germany)

$7202 \mathrm{OH} \quad$ Fiber laser microjoining for novel dissimilar material combinations [7202-16] R. Patwa, H. Herfurth, S. Heinemann, S. Ehrenmann, Fraunhofer Ctr. for Laser Technology (United States); G. Newaz, R. J. Baird, Wayne State Univ. (United States)

7202 Ol Laser-based microbonding using hot melt adhesives [7202-17] G. Hemken, S. Böhm, Technische Univ. Braunschweig (Germany)

$72020 \mathrm{~J} \quad$ Laser soldering of enameled wires [7202-18]

S. Böhm, G. Hemken, K. Noack, Technische Univ. Braunschweig (Germany)

MICRO- AND NANOMACHINING

7202 OK Large-area plasmonic structures fabricated by laser nanopatterning and their applications (Invited Paper) [7202-19]

M. H. Hong, National Univ. of Singapore (Singapore) and Data Storage Institute (Singapore); C. H. Liu, F. Ma, National Univ. of Singapore (Singapore); Z. C. Chen, National Univ. of Singapore (Singapore) and Data Storage Institute (Singapore); B. Luk'yanchuk, L. P. Shi, Data Storage Institute (Singapore); T. C. Chong, National Univ. of Singapore (Singapore) and Data Storage Institute (Singapore) 
$7202 \mathrm{OL}$ Subwavelength photoresist patterning using liquid-immersion interference exposure with a deep-UV hologram mask [7202-20]

D. Sawaki, J. Amako, Seiko Epson Corp. (Japan)

7202 OM Micro-scale large-area UV laser processing [7202-21]

L. Herbst, J. Brune, Coherent GmbH (Germany)

7202 ON Micro ID marking for semiconductor chips: recent progress and future prospects (Invited Paper) [7202-22]

Y. Kokushi, Y. Saitou, A. Mori, Komatsu Engineering Co., Ltd. (Japan)

720200 Micromachining with picosecond double pulses on silicon and aluminium [7202-23]

B. Wojakowski, O. Suttmann, U. Klug, R. Kling, Laser Zentrum Hannover e.V. (Germany)

JOINT SESSION WITH CONFERENCE 7201: PHOTOVOLTAICS

7202 OP Novel laser technologies for crystalline silicon solar cell production (Invited Paper) [7202-24] A. Grohe, A. Knorz, J. Nekarda, U. Jäger, N. Mingirulli, R. Preu, Fraunhofer Institute for Solar Energy Systems (Germany)

$72020 Q$ Thin layer ablation with lasers of different beam profiles: energy efficiency and over filling factor [7202-25]

K. Du, EdgeWave GmbH (Germany)

7202 OR Optical characterization of the heat-affected zone in laser patterning of thin film a-Si:H [7202-26]

C. L. Molpeceres, M. Colina, M. Holgado, M. Morales, I. Sanchez-Aniorte, S. Lauzurica, J. J. Garcia-Ballesteros, J. L. Ocaña, Univ. Politécnica de Madrid (Spain)

7202 OS Laser processing for high-efficiency silicon solar cells (Invited Paper) [7202-27] P. Engelhart, Q-Cells SE (Germany)

7202 OU Optimizing laser beam profiles using micro-lens arrays for efficient material processing: applications to solar cells [7202-29]

D. Hauschild, O. Homburg, T. Mitra, M. Ivanenko, M. Jarczynski, J. Meinschien, A. Bayer, V. Lissotschenko, LIMO Lissotschenko Mikrooptik GmbH (Germany)

Author Index 
Downloaded From: https://www.spiedigitallibrary.org/conference-proceedings-of-spie on 26 Apr 2023

Terms of Use: https://www.spiedigitallibrary.org/terms-of-use 


\title{
Conference Committee
}

\author{
Symposium Chairs
}

Donald J. Harter, IMRA America, Inc. (United States)

Peter R. Herman, University of Toronto (Canada)

Symposium Cochairs

Henry Helvajian, The Aerospace Corporation (United States)

Friedrich G. Bachmann, ROFIN-SINAR Laser GmbH (Germany)

Program Track Chairs

Henry Helvajian, The Aerospace Corporation (United States)

James S. Horwitz, U.S. Department of Energy (United States)

Conference Chairs

Wilhelm Pfleging, Forschungszentrum Karlsruhe (Germany)

Yongfeng Lu, University of Nebraska, Lincoln (United States)

Kunihiko Washio, Paradigm Laser Research Ltd. (Japan)

Conference Cochairs

Willem Hoving, XiO Photonics (Netherlands)

Jun Amako, Seiko Epson Corporation (Japan)

Program Committee

Friedrich G. Bachmann, Rofin-Sinar Laser GmbH (Germany)

Dieter Bäuerle, Johannes Kepler Universität Linz (Austria)

Shaochen Chen, The University of Texas at Austin (United States)

Ramona Eberhardt, Fraunhofer-Institut für Angewandte Optik und Feinmechanik (Germany)

Costas P. Grigoropoulos, University of California, Berkeley (United States)

Bo Gu, IPG Photonics Corporation (United States)

Matthew Henry, Laser Materials Processing Specialist (United Kingdom)

Martin F. Jensen, Danish Technological Institute (Denmark)

Nam Seong Kim, EO Technics (Korea, Republic of)

Thomas Klotzbucher, Institut für Mikrotechnik Mainz GmbH (Germany)

Udo Klotzbach, Fraunhofer-Institut für Werkstoff- und Strahltechnik

(Germany) 
Xinbing Liu, Panasonic Technologies Company (United States)

Tomoaki Matsushima, Panasonic Electric Works Company, Ltd. (Japan)

Andreas Ostendorf, Ruhr-Universität Bochum (Germany)

Marius Przybylski, ATL Lasertechnik GmbH (Germany)

Gurinder P. Singh, Hitachi Global Storage Technologies (United States)

Koji Sugioka, The Institute of Physical and Chemical Research (Japan)

Xiaoyan Zeng, Huazhong University of Science and Technology

(China)

\section{Session Chairs}

1 Optical Components and Devices

Willem Hoving, XiO Photonics (Netherlands)

2 Direct-write Processing and Surface Modification

Yongfeng Lu, University of Nebraska, Lincoln (United States)

3 Modeling and Characterization

Costas P. Grigoropoulos, University of California, Berkeley (United States)

$4 \quad$ Processes for MEMS

Kunihiko Washio, Paradigm Laser Research Ltd. (Japan)

5 Micro- and Nanomachining

Jun Amako, Seiko Epson Corporation (Japan)

6 Joint Session with Conference 7201: Photovoltaics

Wilhelm Pfleging, Forschungszentrum Karlsruhe (Germany) 


\section{Introduction}

At the present time, high-tech industries have increasingly stronger demands for advanced laser-based micro- and nano-packaging and assembly technologies which enable specialized prototypes and high-throughput devices with micro and nanostructures to realize fluidic, biological, electronic, mechanical, and photonic functionalities. Cutting-edge designs and applications are increasingly based on micro- and nano-system technologies. However, the realization of such devices or functional prototypes imposes new challenges for patterning, packaging, and assembly.

Functional systems are continuously becoming more miniaturized and complicated during the course of performance improvement. Nano-materials and nano-patterning technologies become more closely associated with micromaterials and micro-structuring technologies, leading to new applications and research fields, but at the same time imposing new challenges for appropriate assembly and packaging technologies. Due to the ever-increasing complexity of device structures, processing needs for wide varieties of materials and their combinations have been increasing in areas such as MEMS and optofluidics. Furthermore, in certain application fields such as large-area flexible displays and photovoltaics, aspect ratios between horizontal and vertical device features are rapidly increasing. Novel processing technologies with high efficiency and throughput are strongly demanded.

The "Laser-based micro packaging" conference series was established in 2002. In 2007, the conference was renamed "Laser-Based Micro- and Nano- Packaging and Assembly (LBMP)" to reflect the relevance of nanometer-scaled structures. The aim of this conference is to bring together scientists and engineers working on application oriented aspects of laser-based micro- and nano-packaging for mechanical, electronic, photonic, chemical, biological, bio-active, or biocompatible devices including MEMS/bio-MEMS, MOEMS and OLED. Because of the great economical demand, material processing is playing an increasingly important role in current and future LBMP conferences, along with new "green technologies" such as photovoltaics and advanced battery systems.

The conference LBMP-III was held on 28-29 January as part of LASE 2009, at Photonics West in San Jose, California. LBMP-III comprised 6 oral sessions with 29 papers, which were presented by speakers from the USA, Japan, China, Singapore, Spain, Italy, and Germany. Papers represented a number of topics including: modeling and characterization of laser-mater interaction, direct-write processing and surface modification, micro- and nanomachining, processes for optical components and devices, MEMS, and photovoltaics. The photovoltaics session was jointly organized with Conference 7201: Laser Applications in Microelectronic and Optoelectronic Manufacturing XIV (LAMOM-XIV). 
We would like to thank the program committee members and the SPIE technical staff for their great efforts during the planning and organization of LBMP-III. We would also like to thank the invited speakers and presenters of the contributed papers for their contribution to the success of the conference. All the manuscripts were peer reviewed in order to publish high-quality conference proceedings.

Yongfeng Lu Wilhelm Pfleging Kunihiko Washio 